\title{
Characterization of the acute lactational response to trans-10, cis-12 conjugated linoleic acid
}

\author{
K. J. Harvatine ${ }^{1}$ and D. E. Bauman ${ }^{2}$ \\ Department of Animal Science, Cornell University, Ithaca, NY 14853
}

\section{ABSTRACT}

Trans-10, cis-12 conjugated linoleic acid (CLA) is a potent inhibitor of milk fat synthesis in the dairy cow. The decrease in milk fat yield during abomasal infusion of CLA reaches a nadir after 3 to $5 \mathrm{~d}$. The acute responses to CLA were evaluated using 4 cows in a crossover design. Cows were milked with the aid of oxytocin every $4 \mathrm{~h}$ from -28 to $80 \mathrm{~h}$ and every $6 \mathrm{~h}$ from 86 to $116 \mathrm{~h}$ relative to the initiation of abomasal CLA infusion. An initial priming dose of $7.5 \mathrm{~g}$ of CLA was given at time zero followed by infusion of $2.5 \mathrm{~g}$ every $4 \mathrm{~h}$ for $72 \mathrm{~h}$. Plasma CLA reached a near-steady-state concentration by $4 \mathrm{~h}$, and initial plasma enrichments were greatest in the triglyceride and nonesterified fatty acid fractions. Milk CLA concentration peaked at 6 $\mathrm{h}$ and reached steady state by $22 \mathrm{~h}$. At termination of the infusion, decreases in milk CLA concentration and yield and plasma CLA concentration were best fit by a reciprocal-linear function. Milk fat percentage decreased progressively after $2 \mathrm{~h}$ and was significant by $14 \mathrm{~h}$. Milk fatty acid profile was initially unchanged, but between 18 and $36 \mathrm{~h}$ after initiation of the CLA dose the proportions of fatty acids progressively shifted, resulting in an increase in fatty acids $>\mathrm{C} 16$ and a decrease in fatty acids $<\mathrm{C} 16$ by 38 to $46 \mathrm{~h}$. In contrast, changes in the desaturase index were immediate, with a significant decrease by $6 \mathrm{~h}$ and a near-maximal decrease by $10 \mathrm{~h}$. Thus, stearoyl desaturase enzyme was more acutely responsive to CLA than other enzymes in milk fat synthesis. The initial decrease in milk fat synthesis involved an equal depression of short- and long-chain fatty acid pathways and was followed thereafter by a more pronounced decrease in the synthesis of de novo fatty acids.

Key words: milk fat depression, conjugated linoleic acid, desaturase, acute response

\footnotetext{
Received June 26, 2011.

Accepted August 26, 2011.

${ }^{1}$ Current address: 301 Henning Building, Penn State University, University Park 16802.

${ }^{2}$ Corresponding author: deb6@cornell.edu
}

\section{INTRODUCTION}

Milk fat depression (MFD), also referred to as lowfat milk syndrome, is a naturally occurring condition in which milk fat synthesis is specifically decreased and yields of milk and other milk components are unchanged. Diet-induced MFD commonly occurs with diets that are high in either fermentable carbohydrate or polyunsaturated fatty acids (FA). Investigators over the last decade have identified specific FA intermediates of ruminal biohydrogenation as the causative factor of MFD (Harvatine et al., 2009). Trans-10, cis-12 conjugated linoleic acid (CLA) is one of these isomers and its mechanism of action is an active area of investigation (Bauman and Griinari, 2003; Bauman et al., 2011).

Generally, nutritional responses do not show acute phenotypes, although previous experiments with abomasal infusion of trans-10, cis-12 CLA reported a progressive decline in milk fat synthesis, beginning with the first day of CLA treatment, and a maximal response by 3 to $4 \mathrm{~d}$. These experiments reported milk fat yield on a daily or a twice-daily basis, limiting the temporal resolution of the response to CLA (e.g., Baumgard et al., 2000, 2001; Loor and Herbein, 2003). Lactation provides a unique experimental model for a time-course experiment as the amount of milk and milk components collected at each milking represents that produced since the previous milking. Frequent milking allows for a continuous, noninvasive, time-course investigation. In addition, milk yield is a highly repeatable, quantitative observation and representative milk samples can be readily obtained.

Observing the time-course of a response provides insight into biological mechanisms and primary and secondary responses. The objective was characterization of the acute temporal response to trans-10, cis-12 CLA infusion. The CLA was supplied by abomasal infusion at a maximally effective dose, and a time-zero priming bolus of CLA was administered to more rapidly achieve steady-state conditions. In addition, cows were milked at increased frequency to provide higher resolution of the temporal response to CLA. 


\section{MATERIALS AND METHODS}

\section{Animals and Treatments}

All experimental procedures were approved by the Cornell University Institutional Animal Care and Use Committee. Four mid-lactation cows $(133 \pm 36 \mathrm{~d}$ postpartum; mean $\pm \mathrm{SD}$ ) from the Cornell University Teaching and Research Center were assigned randomly to a crossover design. Experimental periods were $14 \mathrm{~d}$ and treatments were control (CON; no infusion) and short-term (72 h) abomasal infusion of trans-10, cis-12 CLA. Cows received a diet that was formulated to meet or exceed NRC nutrient requirements (Table 1; NRC, 2001). Diets were fed ad libitum as a TMR and daily intakes determined. Feed ingredients were dried $\left(55^{\circ} \mathrm{C}\right.$ forced-air oven for $72 \mathrm{~h}$ ) and ground (Wiley mill with 1-mm screen; Arthur H. Thomas, Philadelphia, PA), and nutrient composition determined by wet chemistry procedures (AOCS, 2000; Dairy One Cooperative, Ithaca, NY).

The CLA treatment was infused into the abomasum via $0.5-\mathrm{cm}$ (i.d.) polyvinyl chloride tubing that was passed through the ruminal cannula (Spires et

Table 1. Ingredient and nutrient composition of experimental diets

\begin{tabular}{lc}
\hline $\begin{array}{l}\text { Composition, } \\
\text { \% of DM }\end{array}$ & Concentration \\
\hline Dietary ingredients $^{2}$ & \\
Corn silage $^{2}$ & 33.3 \\
Alfalfa silage $^{2}$ & 9.2 \\
High-moisture corn $^{2}$ & 7.9 \\
Alfalfa hay & 6.8 \\
Whole cottonseed & 6.5 \\
Grain mix & \\
Chemical composition & 36.4 \\
NDF & \\
CP & 31.0 \\
NFC & 17.3 \\
Ether extract & 40.5 \\
\end{tabular}

${ }^{1}$ Diet ingredients and chemical composition do not include abomasally infused conjugated linoleic acid.

${ }^{2}$ On an as-fed basis, corn silage, alfalfa silage, and high-moisture corn were $33.1,38.0$, and $67.4 \%$ of DM, respectively.

${ }^{3}$ Grain mix contained $17.3 \%$ ground corn, $15.0 \%$ wheat middlings, $14.6 \%$ Amino Plus (Ag Processing Inc., Omaha, NE), $14.3 \%$ soybean hulls, $10.5 \%$ corn gluten feed, $7.2 \%$ soybean meal, $5.0 \%$ citrus pulp, $4.7 \%$ dried distillers grains, $3.0 \%$ millruns, $2.8 \%$ limestone, $2.4 \%$ corn gluten meal, $1.8 \%$ sodium sesquicarbonate, $1.1 \%$ salt, $0.74 \%$ urea $0.61 \%$ prilled free fatty acids (Cargill Animal Nutrition, Elk River, MN), $0.26 \%$ yeast (Cargill Animal Nutrition), $0.18 \%$ blood meal, $0.16 \%$ magnesium oxide, $0.10 \%$ trace minerals [contained $(\mathrm{g} / 100 \mathrm{~g})$ : $12.3 \mathrm{Ca}, 12.5$ sulfur, 0.32 magnesium, 1.9 copper, 9.0 manganese, 0.25 cobalt, 0.19 iodine, and 11.0 zinc], 0.09\% Agmate KMS [Cargill Animal Nutrition; contained (g/kg): 112 magnesium, 184 potassium, and 224 sulfur], $0.07 \%$ selenium $(0.06 \% \mathrm{Na}$ selenite), $0.05 \%$ vitamin ADE [contained $(\mathrm{g} / \mathrm{kg}): 10.8$ retinyl acetate, 0.18 cholecalciferol, and 0.047 DL- $\alpha$-tocopherol], 0.04\% Vitamin E (contained $69.1 \mathrm{~g} / \mathrm{kg}$ DL- $\alpha$ tocopherol), and 0.01\% Mepron M85 (Evonik Industries AG, Essen, Germany). al., 1975). A priming dose of $7.5 \mathrm{~g}$ of trans -10 , cis- 12 CLA was infused at time zero followed by infusion of $2.5 \mathrm{~g}$ of trans-10, cis-12 CLA every $4 \mathrm{~h}$ for $72 \mathrm{~h}$. The selected dose was slightly greater than that expected to provide maximal milk fat depression (de Veth et al., 2004). The trans-10, cis-12 CLA (free fatty acid form; Natural ASA, Hovdebygda, Norway) contained 89.0\% trans-10, cis-12 CLA, $2.0 \%$ linolenic acid, and $<0.9 \%$ of any other individual FA.

\section{Milk Sampling and Analysis}

Cows were milked with the aid of oxytocin every 4 $\mathrm{h}$ from -28 to $80 \mathrm{~h}$ and every $6 \mathrm{~h}$ from 86 to $116 \mathrm{~h}$ relative to the initiation of CLA infusion. Oxytocin (5 IU) was administered through an arterial catheter $30 \mathrm{~s}$ before attachment of the milking unit. If cows did not respond to oxytocin, the dose was increased at the next milking and data from both milkings were excluded from analysis (occurred less than once per cow period). Samples were taken at each milking and analyzed for fat and true protein using a mid-infrared spectrophotometer (AOCS, 2000; Dairy One Cooperative). Additional samples for FA analysis were collected and stored at $-20^{\circ} \mathrm{C}$. For milk FA analysis, lipid was extracted according to Hara and Radin (1978) and transmethylated as described by Christie (1982) and modified by Chouinard et al. (1999). Methyl esters were quantified by GLC using a fused-silica capillary column (CP-Sil $88,100 \mathrm{~m} \times 0.25 \mathrm{~mm}$ i.d.; Varian Inc., Palo Alto, CA) according to Perfield et al. (2006). Fatty acid peaks were identified and recoveries quantified using pure methyl ester standards (Nu-Chek Prep, Elysian, MN). In addition, correction factors for individual FA were determined using a butter oil reference standard (CRM 164; Commission of the European Communities, Community Bureau of Reference, Brussels, Belgium). Milk fat yields of individual FA were calculated according to Glasser et al. (2007).

\section{Plasma Sampling and Analysis}

A catheter $(0.065 \mathrm{~cm}$ o.d. $\times 0.03 \mathrm{~cm}$ i.d., microrenathane; Braintree Scientific Inc., Braintree, MA) was placed in the intercostal artery located between the 12 th and 13th ribs as described by Mackle et al. (2000). A blood sample $(20 \mathrm{~mL})$ was collected at each milking in tubes that contained heparin; blood was centrifuged at $2,500 \times g$ for $15 \mathrm{~min}$ and plasma harvested and stored at $-20^{\circ} \mathrm{C}$. Selected time points were analyzed only in the periods when cows received CLA treatment. Plasma lipids were extracted and FA methylated as described by Tyburczy et al. (2008) using $1 \%$ methanolic sulfuric acid. The FA methyl esters were quantified by 
GLC as above with the following modifications: initial oven temperature was $80^{\circ} \mathrm{C}$, and increased $8^{\circ} \mathrm{C} / \mathrm{min}$ to $110^{\circ} \mathrm{C}$, then increased $5^{\circ} \mathrm{C} / \mathrm{min}$ to $170^{\circ} \mathrm{C}$ and held for $10 \mathrm{~min}$, and then increased $4^{\circ} \mathrm{C} / \mathrm{min}$ to $225^{\circ} \mathrm{C}$ and held for $15 \mathrm{~min}$.

Plasma lipid fractions were separated by thin layer chromatography as described by Tyburczy et al. (2008). Four time points following CLA treatment were selected $(4,24,48$, and $120 \mathrm{~h})$, and only samples obtained during CLA treatment were analyzed. Plasma lipid fractions were methylated and analyzed using the same procedures and conditions as described above for total plasma.

\section{Statistical Analysis}

Milk production and milk FA data were analyzed using the Proc Mixed procedure of SAS using a repeated statement (version 9.1, SAS Institute Inc., Cary, NC) according to the following model:

$$
\begin{aligned}
\mathrm{Y}_{\mathrm{ijklm}}=\mu & +\mathrm{P}_{\mathrm{i}}+\mathrm{S}_{\mathrm{j}}+\mathrm{C}_{\mathrm{k}}\left(\mathrm{S}_{\mathrm{j}}\right)+\mathrm{T}_{\mathrm{l}}+\mathrm{H}_{\mathrm{m}} \\
& +\mathrm{T}_{\mathrm{l}} \times \mathrm{H}_{\mathrm{m}}+\mathrm{e}_{\mathrm{ij} \mathrm{jlm}},
\end{aligned}
$$

where $Y_{\mathrm{ijklm}}$ is the variable of interest, $\mu$ is the overall mean, $\mathrm{P}_{\mathrm{i}}$ is the random effect of period ( $\mathrm{i}=1$ to 2 ), $\mathrm{S}_{\mathrm{j}}$ is the random effect of sequence $(\mathrm{j}=1$ to 2$), \mathrm{C}_{\mathrm{k}}\left(\mathrm{S}_{\mathrm{j}}\right)$ is the random effect of cow nested in sequence $(\mathrm{k}=1$ to 4), $T_{1}$ is the fixed effect of treatment ( $1=1$ to 2$), \mathrm{H}_{\mathrm{m}}$ is the fixed effect of time, $\mathrm{T}_{1} \times \mathrm{H}_{\mathrm{m}}$ is the interaction of treatment and time, and $\mathrm{e}_{\mathrm{ijklm}}$ is the residual error. Because of a numerical treatment difference at time 0 , the sum of milk FA $<16$ and $>16$ carbons was analyzed relative to pre-bolus profile. Repeated measures over time were calculated using the autoregressive or heterogeneous autoregressive covariance structure depending on model fit. Denominator degrees of freedom were estimated using the Kenward-Rogers method. Data points with Studentized residuals $>3.0$ were considered outliers and excluded from analysis; few points were excluded and rarely more than one per response variable. Preplanned contrasts included the effect of CLA (CON vs. CLA) at each time point. For clarity, means at $0 \mathrm{~h}$ are reported in Table 2, and treatment response over time is reported as the difference between treatments (CLA - CON). Milk variables are plotted as the median time of the milking interval because milk represents that synthesized over the interval between milkings. A reduced model of the above was used for plasma variables and included sequence, cow(sequence), period, and time. Preplanned contrasts tested the effect of time by comparing each time point to pre-CLA infusion. Concentrations of CLA in plasma fractions at different times after initiation of CLA infusion were separated using protected LSD.

The relationship between CLA concentration in plasma or milk and time after last CLA infusion was derived by regression analysis. The best-fit function was selected based on the adjusted $\mathrm{R}^{2}$ and $P$-value. Regression curves were fit independently for each cow-period and the average relationship presented was calculated as the mean of intercept and slope of the individual regressions.

\section{RESULTS}

\section{Milk and Plasma CLA}

Milk fat concentration of trans-10, cis-12 CLA was negligible before treatment $(<0.01 \%$ of FA), peaked 6

\begin{tabular}{|c|c|c|c|c|}
\hline \multirow[b]{2}{*}{ Variable } & \multicolumn{2}{|c|}{ Pretreatment $^{1}$} & \multirow[b]{2}{*}{ SEM } & \multirow[b]{2}{*}{$P$-value ${ }^{2}$} \\
\hline & $\mathrm{CON}$ & CLA & & \\
\hline Milk yield, $\mathrm{kg} / \mathrm{h}$ & 1.78 & 1.68 & 0.34 & 0.87 \\
\hline \multicolumn{5}{|l|}{ Milk fat } \\
\hline$\%$ & 3.40 & 3.39 & 0.32 & 0.96 \\
\hline $\mathrm{g} / \mathrm{h}$ & 56 & 57 & 6 & 0.98 \\
\hline \multicolumn{5}{|l|}{ Milk protein } \\
\hline$\%$ & 2.76 & 2.92 & 0.20 & 0.27 \\
\hline $\mathrm{g} / \mathrm{h}$ & 44 & 44 & 6 & 0.99 \\
\hline \multicolumn{5}{|c|}{ Milk fatty acid source, ${ }^{3} \%$ of total } \\
\hline$<16$ carbons & 22.8 & 23.1 & 1.30 & 0.62 \\
\hline 16 carbons & 30.1 & 29.5 & 2.9 & 0.53 \\
\hline$>16$ carbons & 44.5 & 44.3 & 3.5 & 0.92 \\
\hline
\end{tabular}

Table 2. Pretreatment average milk yield and composition 
to $10 \mathrm{~h}$ after the priming dose, and reached a relatively stable concentration by $22 \mathrm{~h}$ that was maintained for the duration of the 72 -h period of abomasal infusion (mean \pm SD: $0.41 \pm 0.04 \%$ of total FA between 22 to $74 \mathrm{~h}$; Figure 1a). Secretion of trans-10, cis-12 CLA in milk fat followed a similar pattern, and averaged $0.17 \pm$ $0.02 \mathrm{~g} / \mathrm{h}$ of total FA over 22 to $74 \mathrm{~h}$ of infusion (mean $\pm \mathrm{SD}$; Figure $1 \mathrm{~b}$ ). As a proportion of total plasma FA, CLA concentration was $0.17 \%$ of FA at $4 \mathrm{~h}$ after the priming dose and averaged $0.17 \pm 0.01 \%$ of total FA for the interval of 22 to $72 \mathrm{~h}$ of the infusion period (mean $\pm \mathrm{SD}$; Figure 2a). To characterize the relationship between plasma and milk CLA, we tested the ratio of plasma:milk CLA concentration. The ratio peaked 8 to $12 \mathrm{~h}$ after the priming dose and reached a steady-state ratio of approximately $2.5 \pm 0.25$ (mean 24 to $72 \mathrm{~h} \pm$ SD; Figure 2b).

Data were collected for an extended period after infusion ceased to observe the posttreatment transition. The CLA decreased in plasma (Figure 2) and milk (Figure 1) after termination of CLA infusion, and the rate of decay best fit a reciprocal linear function (plasma CLA mean $\mathrm{R}^{2}=0.95, P<0.01 ;$ milk CLA concentration mean $\mathrm{R}^{2}=0.98, P<0.001$; milk CLA yield mean $\mathrm{R}^{2}$ $=0.97, P<0.01 ;$ Figure 3a to $\mathrm{c}$ ). Interestingly, the plasma:milk ratio also decreased after termination of CLA infusion as shown in Figure 2b.

Plasma concentration of trans-10, cis-12 CLA was negligible before CLA infusion, but after the priming dose, trans-10, cis-12 CLA was predominantly enriched in the NEFA and triglyceride (TG) fractions (1.36 and $2.74 \%$ of total FA, respectively; Table 3). After 24 and $48 \mathrm{~h}$ of infusion, CLA was $0.20 \%$ of total FA in the phospholipid (PL) fraction, but represented an even higher enrichment in the TG and NEFA fractions (0.45 to $1.03 \%$ of total $\mathrm{FA}$ in each fraction). By $48 \mathrm{~h}$ after termination of CLA infusion (120 h time point), the concentration of trans-10, cis-12 CLA in the TG and NEFA fractions had decreased by 70 and $66 \%$, respectively, and the concentration in PL had decreased by $54 \%$.

\section{Milk Fat Synthesis}

Milk fat percentage decreased progressively, with the difference being significant by $14 \mathrm{~h}$ after the priming dose (Figure 4a). The decrease in milk fat percentage reached near nadir by $42 \mathrm{~h}$ and was maintained for the duration of the infusion period. This nadir represented a $43 \pm 5.2 \%$ decrease (mean $\pm \mathrm{SD}$ ) over the interval of 42 to $74 \mathrm{~h}$. Treatment did not affect milk yield (data not shown), thus milk fat yield followed a similar pattern to milk fat percentage (Figure $4 \mathrm{~b}$ ).
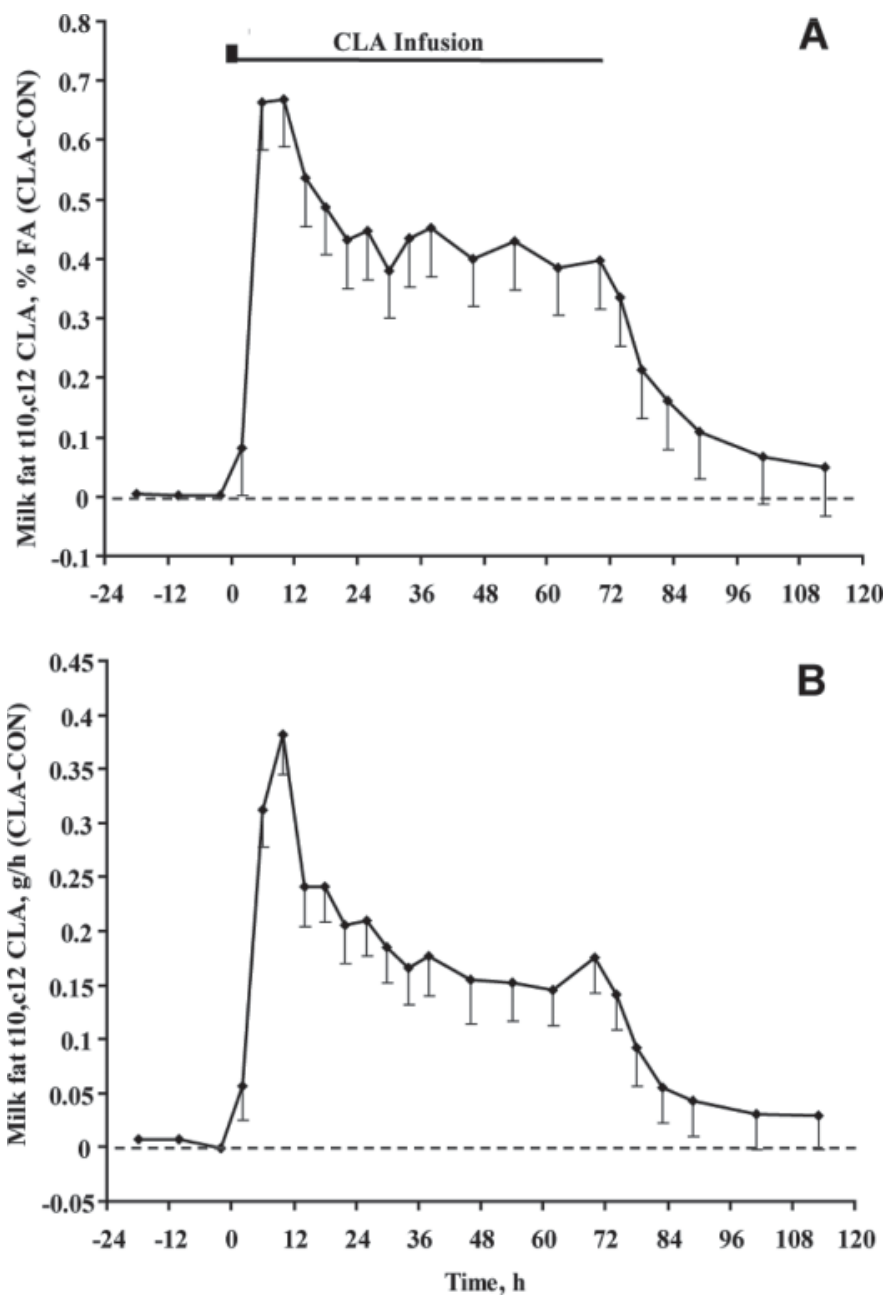

Figure 1. Temporal response of the concentration and secretion of trans-10, cis-12 conjugated linoleic acid (CLA) in milk fat during abomasal infusion of CLA (0 to $72 \mathrm{~h}$ ). (A) Concentration of trans-10, cis-12 CLA in milk fat as a percentage of total fatty acid (FA) and (B) rate of trans-10, cis-12 CLA secretion in milk fat. Values are the difference between control and CLA treatment least squares means (CON minus CLA), error bars represent standard error of the difference (SED), and values are plotted at the median time of the milking interval. Preplanned contrast tested if CLA treatment differed from control. Both CLA concentration and rate of synthesis differed from control from 6 to $74 \mathrm{~h}(P<0.001)$ and at $78 \mathrm{~h}(P<0.05)$.

\section{De Novo and Preformed FA Response}

Interestingly, modification of the milk FA profile followed a different time course than that of milk fat yield. Milk FA composition was initially unchanged, but the pattern of milk FA progressively shifted 18 to $22 \mathrm{~h}$ after the priming dose, resulting in a decrease in the proportion of $\mathrm{FA}<\mathrm{C} 16$ and an increase in those $>$ C16 (Figure 5a and b). Similar to milk fat percentage, yields of preformed FA ( $>16$ carbons) and de novo FA ( $<16$ carbons) decreased progressively following the 

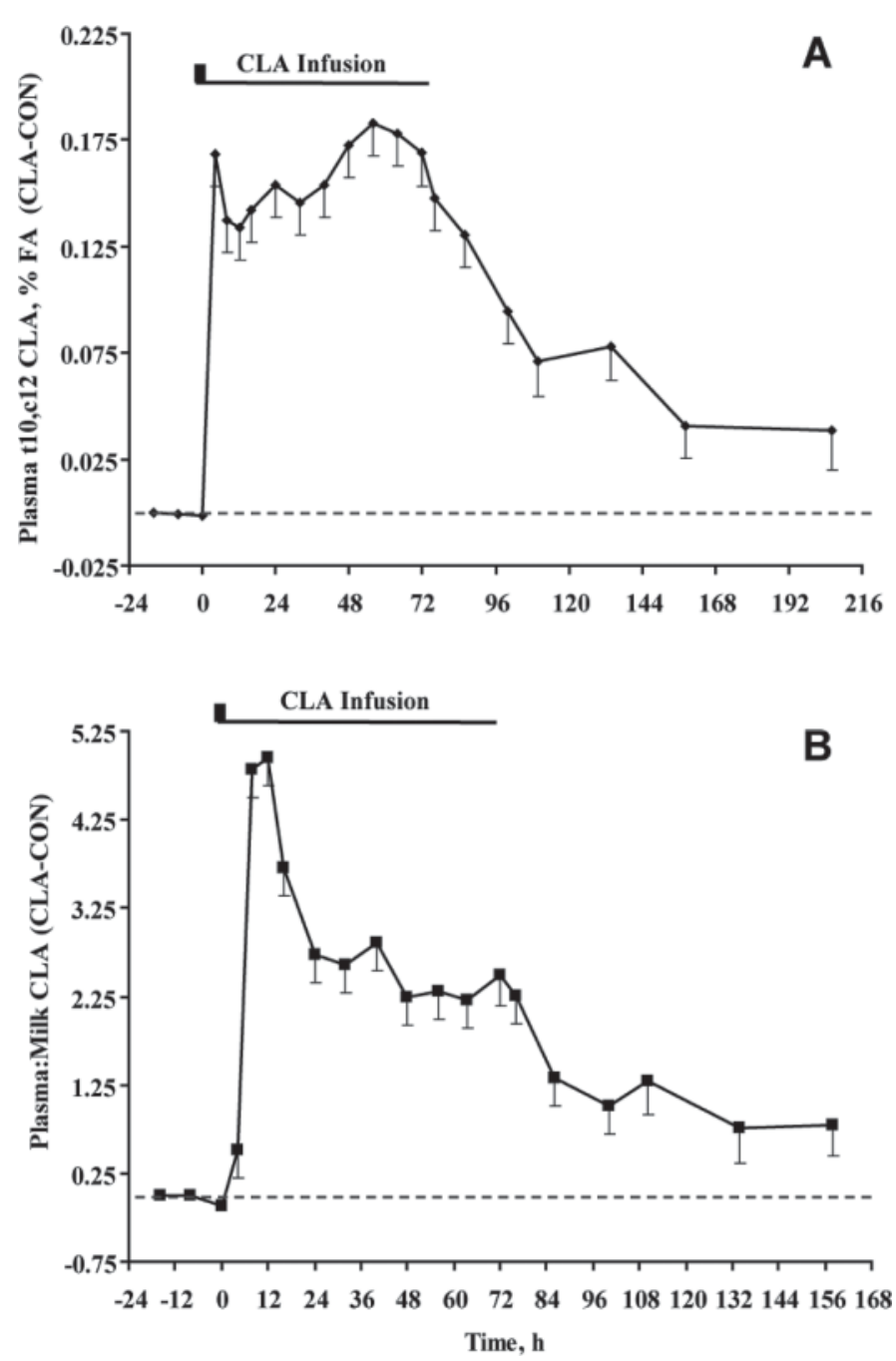

Figure 2. Temporal response of plasma trans-10, cis-12 conjugated linoleic acid (CLA) during abomasal infusion of CLA (0 to $72 \mathrm{~h}$ ). (A) Plasma trans-10, cis-12 CLA concentration as a percentage of total plasma fatty acids (FA) and (B) ratio of the trans-10, cis-12 CLA concentration in plasma to the concentration in milk. Values are least squares means, error bars represent SEM, and values are plotted at the time of blood sampling. Preplanned contrast tested if individual time points after initiation of CLA infusion differed from preinfusion values. Plasma CLA concentration differed from preinfusion from 4 to $134 \mathrm{~h}(P<0.001)$, at $158 \mathrm{~h}(P<0.01)$, and at $206 \mathrm{~h}(P<0.05)$. The ratio of plasma to milk CLA concentration differed from preinfusion from 8 to $86 \mathrm{~h}(P<0.001)$, from 100 to $110 \mathrm{~h}(P<0.01)$, and at 158 h $(P<0.05)$.

initiation of infusion, but were not significantly reduced until 30 and $38 \mathrm{~h}$, respectively (data not shown).

\section{Milk Desaturase Pairs}

The substrate-product relationship for the stearoylCoA desaturase enzyme (EC 1.14.19.1) has been used as a proxy for activity of this enzyme (Kelsey et al., 2003). All 3 of the observed desaturase pairs, C14, C16, and
C18, were decreased by $6 \mathrm{~h}$ after the priming dose of CLA and initiation of CLA infusion, and they reached a nadir at about $10 \mathrm{~h}$ (Figure 6). The $\mathrm{C} 14$ desaturase index maintained this nadir level for the duration of the infusion period, but the $\mathrm{C} 16$ and $\mathrm{C} 18$ desaturase indices partially recovered and were not different from those of the control from 34 to $54 \mathrm{~h}$.

\section{DISCUSSION}

Investigations of MFD have focused on characterizing animal metabolism and cellular events during sustained MFD (Bauman et al., 2008; Harvatine et al., 2009). However, this approach may be complicated by the presence of secondary adaptations to reduced milk fat synthesis, which could limit the ability to identify primary causative regulatory events associated with the reduction in mammary milk fat synthesis. Lactation is conducive to time-course measurements because milk synthesis is continuous and milking offers a noninvasive approach to evaluate the synthesized product. Dairy cows are normally milked at 8- to 12-h intervals, and this milking frequency can be easily increased to every $4 \mathrm{~h}$ with the administration of oxytocin to standardize milk let-down and reduce residual milk. Thus, milk and milk components collected at each milking represent the amount of milk synthesized over the interval between milkings.

Quickly achieving a steady-state level for a treatment is important when defining the time course of a response. A priming dose of CLA was used in the current experiment to reduce the lag time between initiation of CLA infusion and delivery of an effective dose of CLA to the mammary gland. A short lag time was expected due to the time required for CLA absorption, packaging, and transport to the mammary gland as well as the CLA-induced mammary cellular events that decrease the synthesis and subsequent secretion of milk fat. The priming dose reduced the lag time as near-steady-state plasma CLA concentrations were achieved by $4 \mathrm{~h}$ after the initiation of CLA infusion. In addition, milk fat CLA concentrations peaked $6 \mathrm{~h}$ after the priming dose in agreement with isotope studies showing a 4- to 6-h lag before the uptake and secretion of radiolabeled dietary FA in milk fat (Annison et al., 1967; Hachey et al., 1987).

Plasma FA are transported in different lipid fractions, which has important implications in FA metabolism. The plasma lipid fractions differ in turnover, and most FA uptake by the mammary gland occurs from the plasma TG and NEFA fractions, with a much lower capacity for uptake from other plasma lipid fractions (Annison et al., 1967; Noble, 1978; Moore and Christie, 1979). In addition, plasma lipid fractions have a 
markedly different FA profile; for example, linoleic acid makes up over half of the total FA in cholesterol esters but $<5 \%$ of the FA in circulating TG (Tyburczy et al., 2008). Loor and Herbein (2003) and Perfield et al. (2006) reported that CLA were in the greatest enrichment in the plasma TG and NEFA fractions (\% total fatty acids in the fraction) with lower incorporation into PL after 2 and $4 \mathrm{~d}$ of CLA treatment, respectively. In the current experiment, CLA enrichment first occurred in the TG and NEFA fractions following the priming dose (Table 3). After a longer term infusion of CLA, enrichment was observed in the plasma PL fraction. When CLA infusion was terminated, the concentration of CLA decreased in all plasma lipid fractions, but the initial decrease was more extensive in the TG and NEFA fractions compared with the PL fraction. The temporal pattern of CLA enrichment in plasma lipid fractions is related in part to differences in turnover rates of these fractions (Noble, 1978; Moore and Christie, 1979), and the dynamics of CLA enrichment into plasma pools provide insight into the plasma:milk CLA ratio (Figure 2b). The initial peak in the ratio is due to the high enrichment of CLA in the plasma TG and NEFA fractions and the extensive mammary uptake of FA from these fractions, whereas the lower ratio after termination of CLA infusion represents a higher proportion in PL fractions that are less extensively utilized for FA uptake by the mammary gland.

Because CLA reached steady-state conditions during CLA infusion, approaches normally used with tracer techniques can be applied to characterize the metabolism of CLA. The decrease in the concentration and secretion of CLA in milk fat and plasma concentration of CLA after termination of infusion best fit a reciprocal-linear function with a high $\mathrm{R}^{2}$ (0.95 to 0.98; Figure 3). Modeling FA metabolism is complicated because FA are found in multiple plasma and cellular pools that have different turnover rates and metabolic routes as previously discussed (Noble, 1978; Moore and Christie, 1979). A strong predictive relationship was derived between the decrease of CLA in milk and plasma, which provides a novel characterization of the rate of CLA metabolism in the dairy cow.

Synthesis of both de novo and preformed FA are decreased during MFD; however, a larger decrease occurs in de novo synthesized FA with more severe MFD (Baumgard et al., 2001). A distinct temporal response was observed in the proportions of de novo and preformed FA. Although total milk fat synthesis progressively decreased over the first day of CLA infusion, milk FA profile did not change during the first 18 h. Between 18 and $36 \mathrm{~h}$, a distinct decrease occurred in the proportion of de novo synthesized FA (Figure $5 \mathrm{a}$ and $\mathrm{b}$ ). Thus, the shift in FA profile represented
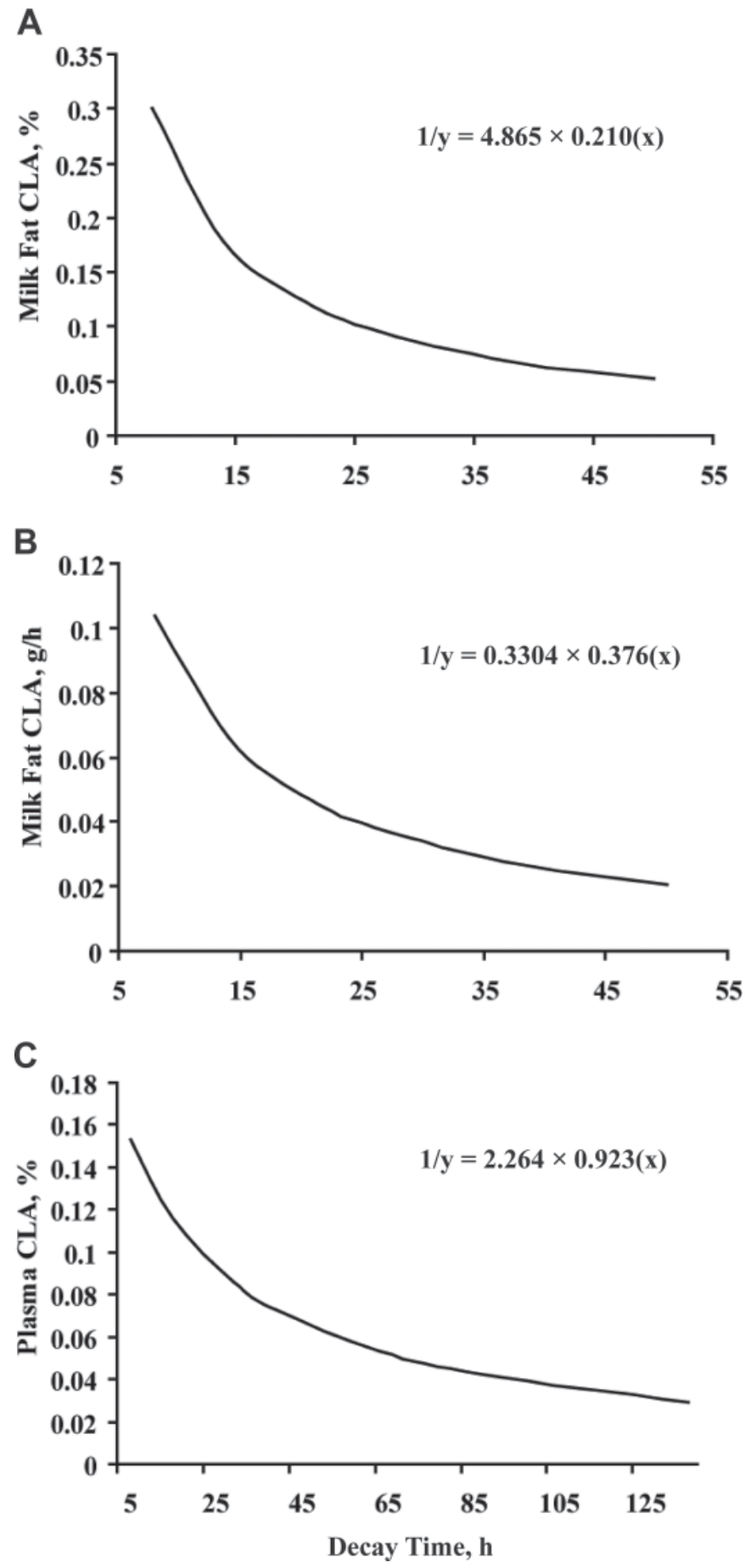

Figure 3. Predicted decay of trans-10, cis-12 conjugated linoleic acid (CLA) in milk fat and plasma after the termination of CLA infusion based on the best-fit function in 4 cows. The reciprocal linear function was fit to data of individual cows and the presented curves were derived as the mean of the slope and intercept of the individually fit functions. (A) Relationship between milk fat CLA concentration and time after termination of CLA infusion $\left(P<0.001, \mathrm{R}^{2}=0.98\right)$; (B) relationship between rate of CLA secretion in milk fat and time after termination of CLA infusion $\left(P<0.01, \mathrm{R}^{2}=0.97\right)$; and $(\mathrm{C})$ relationship between plasma CLA concentration as a percentage of total plasma fatty acid (FA) and time after termination of CLA infusion $(P$ $\left.<0.01, \mathrm{R}^{2}=0.95\right)$ 
Table 3. Proportion of trans-10, cis-12 conjugated linoleic acid (CLA) in various plasma lipid fractions

\begin{tabular}{lccccrcc}
\hline & \multicolumn{9}{c}{ Time $^{1}$} & & \\
\cline { 2 - 5 } Variable & $4 \mathrm{~h}$ & $24 \mathrm{~h}$ & $48 \mathrm{~h}$ & $120 \mathrm{~h}$ & SEM & $P$-value \\
\hline NEFA, \% of FA & $1.36^{\mathrm{b}}$ & $0.66^{\mathrm{b}}$ & $1.03^{\mathrm{b}}$ & $0.31^{\mathrm{a}}$ & 0.36 & 0.02 \\
Triglyceride, \% of FA & $2.74^{\mathrm{c}}$ & $0.64^{\mathrm{b}}$ & $0.45^{\mathrm{b}}$ & $0.15^{\mathrm{a}}$ & 0.52 & $<0.001$ \\
Phospholipids, \% of FA & $0.05^{\mathrm{c}}$ & $0.20^{\mathrm{b}}$ & $0.21^{\mathrm{b}}$ & $0.10^{\mathrm{a}}$ & 0.01 & $<0.001$ \\
Cholesterol ester, \% of FA & $0.01^{\mathrm{c}}$ & $0.06^{\mathrm{b}}$ & $0.05^{\mathrm{bc}}$ & $0.11^{\mathrm{a}}$ & 0.02 & $<0.01$ \\
\hline
\end{tabular}

${ }^{\mathrm{a}-c}$ Means within a row with different superscripts differ $(P<0.05)$.

${ }^{1}$ Time after initiation of trans-10, cis-12 CLA infusion. Trans-10, cis-12 CLA was below the level of detection $(<0.01 \%$ of fatty acids, FA) in total plasma before the CLA infusion. Values are least squares means for the concentration of trans-10, cis-12 CLA as a percentage of FA in the specified plasma fraction. Means were separated using a protected LSD.

${ }^{2}$ Probability of an effect of time.
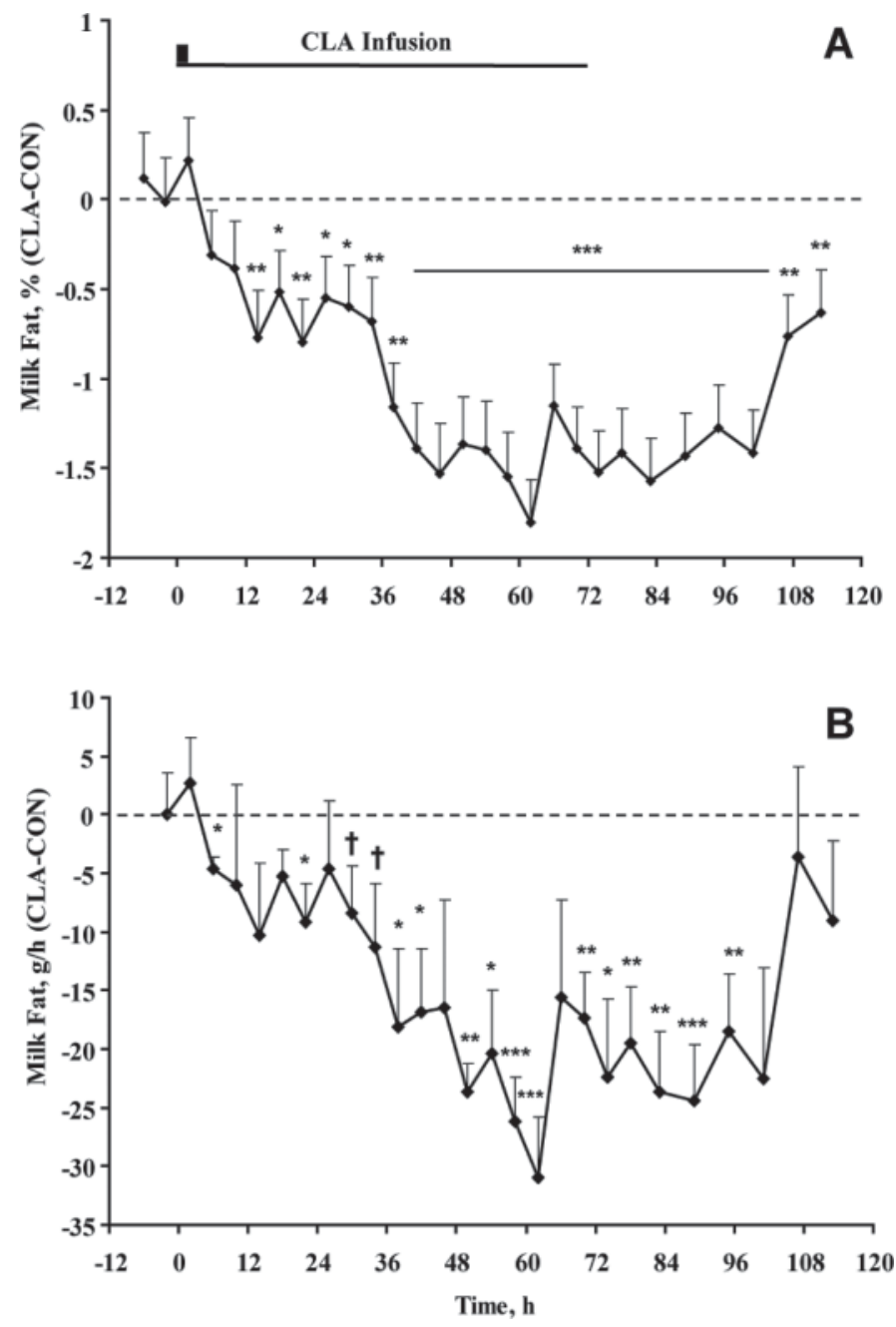

Figure 4. Temporal response of milk fat during abomasal infusion of trans-10, cis-12 conjugated linoleic acid (CLA; 0 to $72 \mathrm{~h}$ ). (A) Milk fat percentage and $(\mathrm{B})$ rate of milk synthesis. Values are the difference between control and CLA treatment least squares means (CON minus CLA), error bars represent standard error of the difference (SED), and values are plotted at the median time of the milking interval. Preplanned contrast tested if CLA infusion differed from control and significance at each time point is shown: $\dagger P<0.10$; ${ }^{*} P<0.05$; ${ }^{*} P<$ $0.01 ; * * * P<0.001$. a 2-phase response that is schematically presented in Figure 7. During the initial phase over the first $18 \mathrm{~h}$, the decrease in milk fat synthesis involved an equal depression in FA derived from the pathways associated with de novo synthesis and the uptake of preformed FA. In contrast, the second phase was characterized by a more pronounced decrease in de novo synthesized FA (Figure 7). In previous experiments with twice-daily milking, Baumgard et al. (2000) similarly observed no change in the proportion of de novo synthesized FA until the second day of CLA infusion. Loor and Herbein (2003) reported an approximately $21 \%$ decrease in milk fat yield by the second 12-h milking interval in CLAinfused cows with a shift (approximately 6\% greater decrease) in the proportion of de novo synthesized FA.

Numerous investigations have characterized the phenotype of CLA-induced MFD (Harvatine et al., 2009), and the present experiment describes the time course of the response to trans-10, cis-12 CLA. Cellular signaling events induced by CLA would precede the decrease in lipid synthesis and may involve either reduced amount or reduced activity of rate-limiting enzymes. The amount of an enzyme can be controlled by transcription, translation, and protein turnover, whereas enzyme activity can be altered by posttranslational modification (e.g., phosphorylation) of the enzyme. The lag between delivery of trans-10, cis-12 CLA to the mammary, modification of cellular signaling, and reduced lipid synthesis depends on the mechanisms involved. A coordinated decrease in the expression of rate-limiting enzymes of milk fat synthesis and downregulation of 2 regulators of lipid synthesis, sterol-response element binding protein 1 (SREBP1) and thyroid hormone responsive spot 14 (S14), were reported during established MFD (Harvatine and Bauman, 2006). Interestingly, Kim et al. (2010) reported that a spot 14-related protein catalyzes the transition of acetyl-CoA carboxylase from inactive monomers to active polymers. Early phase mechanisms have not been investigated and the acute 

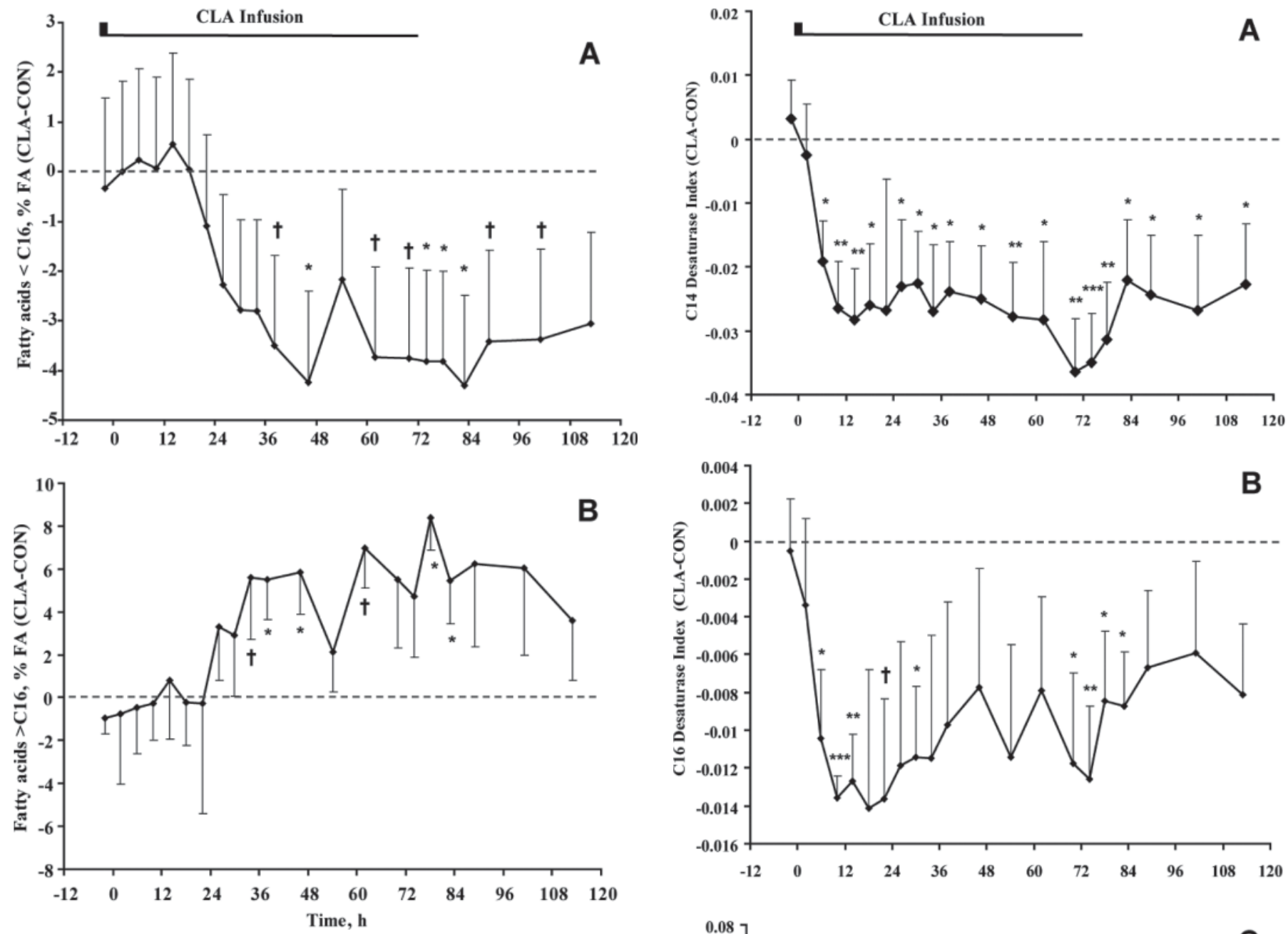

Figure 5. Temporal response of milk fatty acid (FA) composition as a percent of total FA during abomasal infusion of trans-10, cis-12 conjugated linoleic acid (CLA; 0 to $72 \mathrm{~h}$ ). (A) Concentration of FA $<16$ carbons, and (B) concentration of FA $>16$ carbons. Values are the difference between control and CLA treatment least squares means (CON minus CLA), error bars represent standard error of the difference (SED), and values are plotted at the median time of the milking interval. Preplanned contrast tested if CLA infusion differed from control and significance at each time point is shown: $\dagger P<0.10$; ${ }^{*} P<$ $0.05 ;{ }^{* *} P<0.01 ; * * * P<0.001$.

response observed in the current experiment provides the possibility for classic rapid regulatory systems that function at the level of protein stability and activity.

Abomasal infusion of CLA and the use of a priming dose quickly established steady-state delivery of CLA to the mammary gland, allowing the current experiment to demonstrate the temporal response of the mammary gland to trans-10, cis-12 CLA. In application, MFD results from altered ruminal fermentation caused by dietary factors. Shingfield et al. (2006) reported the temporal response of milk fat yield and milk FA profile of cows fed a diet that induced MFD. The milk fat con-

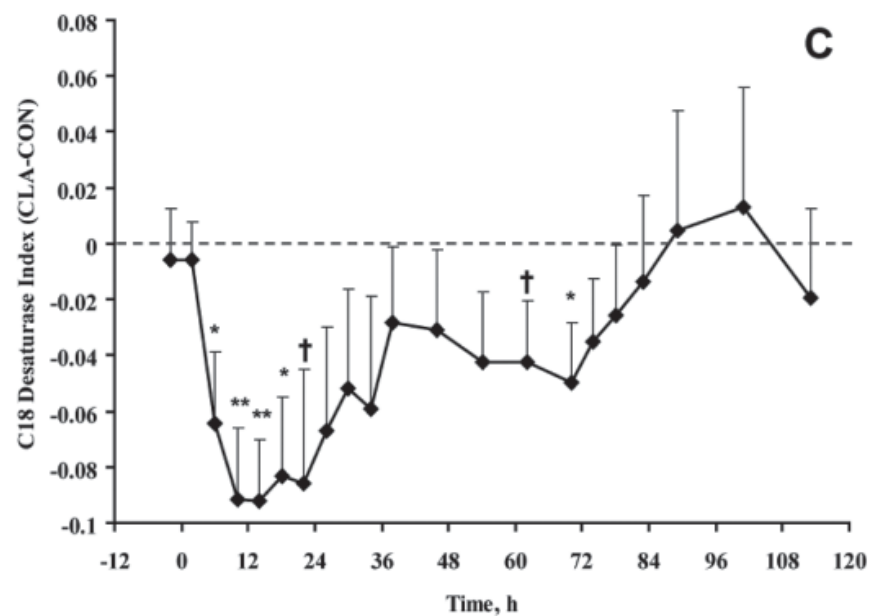

Figure 6. Temporal response of milk fat desaturase index during abomasal infusion of trans-10, cis-12 conjugated linoleic acid (CLA; 0 to $72 \mathrm{~h})$. (A) C14 index [C14:1/(C14:0 + C14:1)]; (B) C16 index $[\mathrm{C} 16: 1 /(\mathrm{C} 16: 0+\mathrm{C} 16: 1)]$; and (C) C18 index $[$ cis-9 C18:1/(C18:0 + cis-9 C18:1)]. Values are the difference between control and CLA treatment least squares means (CON minus CLA), error bars represent standard error of the difference (SED), and values are plotted at the median time of the milking interval. Preplanned contrast tested if CLA infusion differed from control and significance at each time point is shown: $\dagger P<0.10{ }^{*} P<0.05 ;{ }^{* *} P<0.01 ;{ }^{* * *} P<0.001$. 


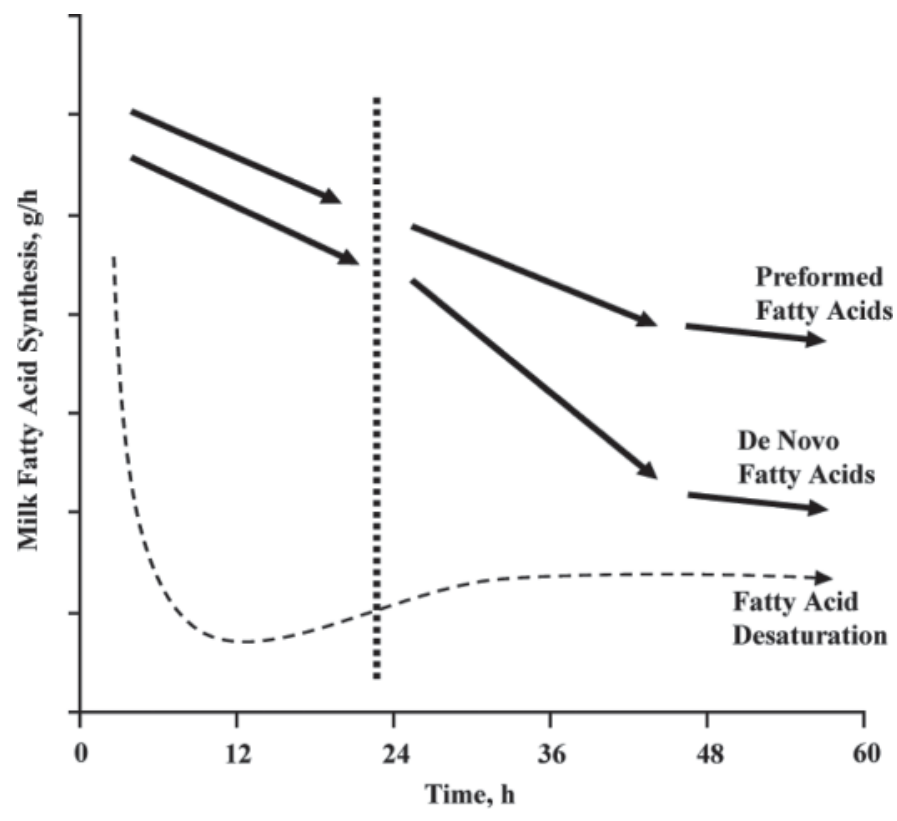

Figure 7. Schematic representation of temporal pattern of changes observed during abomasal infusion of trans-10, cis-12 conjugated linoleic acid.

tent of specific CLA and trans FA isomers associated with MFD progressively increased until d 16, and then maintained a stable concentration for the remainder of the feeding period. Milk fat yield progressively decreased after 6 to $8 \mathrm{~d}$ of treatment with a nadir reached at approximately $18 \mathrm{~d}$. The gradual appearance of alternate biohydrogenation intermediates and the long lag before decreased milk fat yield in diet-induced MFD showed that ruminal adaptation to a MFD diet was much slower than the mammary gland's response to CLA isomers. Satter and Bringe (1969) investigated the acute response to an MFD diet by switching rumen contents between cows fed high-forage or low-forage diets, cows on the latter diet being MFD; simultaneously switching rumen contents and diet resulted in $70 \%$ of the maximal reduction in milk fat by $3 \mathrm{~d}$ and complete MFD within 5 to $6 \mathrm{~d}$. This provides further support that the mammary gland is acutely sensitive to the products of altered ruminal fermentation, but the reduction in milk fat during diet-induced MFD typically involves a more extended period that is associated with the ruminal adaptations.

Milk fat desaturase index is commonly used as a proxy for the activity of the stearoyl-CoA desaturase (SCD) enzyme (Harvatine et al., 2009). In the current experiment, the effect of CLA on the desaturase index was more acute than the effect of CLA on milk fat synthesis, with a near-maximal response observed $6 \mathrm{~h}$ after the priming dose. Loor and Herbein (2003) reported a near-maximal decrease in the desaturase index in the second 12-h milking interval after CLA infusion. The SCD enzyme is primarily regulated at the level of translation and mRNA stability (Ntambi, 1999) and has a very short half-life of 2 to $4 \mathrm{~h}$ (Oshino and Sato, 1972; Toyama et al., 2007). In contrast, the halflives of acetyl-CoA carboxylase (EC 6.4.1.2) and fatty acid synthase (EC 2.3.1.85) are 48 to $76 \mathrm{~h}$ in well-fed conditions and decrease to 18 to $31 \mathrm{~h}$ during fasting in rodents (Craig et al., 1972; Volpe and Vagelos, 1973; Volpe and Marasa, 1975). Increased rates of enzyme turnover allow changes associated with transcriptional regulation to be more acutely apparent. Alternatively, trans-10, cis-12 CLA may competitively inhibit the activity of the SCD enzyme, or SCD may be responsive to different or additional cellular signals that are stimulated by CLA compared with other enzymes involved in the regulation of milk fat synthesis.

The decreased FA desaturation preceded inhibition of milk fat synthesis, but the inhibition of FA desaturation was not likely the direct cause of MFD based on other published investigations (reviewed by Harvatine et al., 2009). Briefly, some isomers of CLA that decreased the desaturase index did not cause MFD, and inhibition of the SCD enzyme by sterculic acid or CoEDTA dramatically reduced FA desaturation without any effect on milk fat synthesis. Last, CLA reduction of adiposity in mice was independent of the SCD enzyme as CLA reduced body fatness in the SCD1 null mouse (Kang et al., 2004).

\section{CONCLUSIONS}

Abomasally infused trans-10, cis-12 CLA was incorporated into milk fat within $6 \mathrm{~h}$, and steady-state concentrations were quickly established by use of a priming dose. The reduction in milk fat synthesis was progressive, beginning $2 \mathrm{~h}$ after the priming dose, and was significant by $14 \mathrm{~h}$. The decrease in milk fat synthesis over the initial $18 \mathrm{~h}$ involved an equal depression in FA from all sources and this was followed by a more pronounced decrease in the milk FA derived from de novo synthesis. The desaturase enzyme was more acutely responsive to CLA with a near-maximal decrease in the desaturase index occurring by $10 \mathrm{~h}$. Characterization of the temporal reduction in milk fat synthesis provides insight into the mechanism of biohydrogenation intermediates and essential information for future experiments to probe the mechanisms for the regulation of milk fat synthesis and fatty acid desaturation.

\section{ACKNOWLEDGMENTS}

The authors specifically recognize the support and technical assistance of D. A. Dwyer (Cornell University, 
Ithaca, NY). Additionally, the authors acknowledge the assistance of Cornell University colleagues J. W. Perfield, M. R. Waldron, M. Tanino, C. Tyburczy, E. Castañeda-Gutiérrez, A. L. Lock, L. Furman, B. English, W. Waybright, and A. Garcia-Ramirez in the conduct of this research. Research supported in part by National Research Initiative Competitive Grants no. 2006-35206-16643 from the USDA Cooperative State Research, Education, and Extension Service, Agriculture and Food Research Initiative Competitive Grant no. 2010-65206-20723 from the USDA National Institute of Food and Agriculture, and Cornell Agricultural Experiment Station.

\section{REFERENCES}

Annison, E. F., J. L. Linzell, S. Fazakerley, and B. W. Nichols. 1967. The oxidation and utilization of palmitate, stearate, oleate and acetate by the mammary gland of the fed goat in relation to their overall metabolism, and the role of plasma phospholipids and neutral lipids in milk-fat synthesis. Biochem. J. 102:637-647.

AOCS. 2000. Official Methods of Analysis. 17th ed. Association of Official Analytical Chemists, Arlington, VA.

Bauman, D. E., and J. M. Griinari. 2003. Nutritional regulation of milk fat synthesis. Annu. Rev. Nutr. 23:203-227.

Bauman, D. E., K. J. Harvatine, and A. L. Lock. 2011. Nutrigenomics, rumen-derived bioactive fatty acids, and the regulation of milk fat synthesis. Annu. Rev. Nutr. 31:299-319.

Bauman, D. E., J. W. Perfield II, K. J. Harvatine, and L. H. Baumgard. 2008. Regulation of fat synthesis by conjugated linoleic acid: Lactation and the ruminant model. J. Nutr. 138:403-409.

Baumgard, L. H., B. A. Corl, D. A. Dwyer, A. Saebo, and D. E. Bauman. 2000. Identification of the conjugated linoleic acid isomer that inhibits milk fat synthesis. Am. J. Physiol. Regul. Integr. Comp. Physiol. 278:R179-R184

Baumgard, L. H., J. K. Sangster, and D. E. Bauman. 2001. Milk fat synthesis in dairy cows is progressively reduced by increasing supplemental amounts of trans-10, cis-12 conjugated linoleic acid (CLA). J. Nutr. 131:1764-1769.

Chouinard, P. Y., L. Corneau, D. M. Barbano, L. E. Metzger, and D E. Bauman. 1999. Conjugated linoleic acids alter milk fatty acid composition and inhibit milk fat secretion in dairy cows. J. Nutr. 129:1579-1584.

Christie, W. W. 1982. A simple procedure for the rapid transmethylation of glycerolipids and cholesterol esters. J. Lipid Res. $23: 1072-1075$

Craig, M. C., C. M. Nepokroeff, M. R. Lakshmanan, and J. W. Porter. 1972. Effect of dietary change on the rates of synthesis and degradation of rat liver fatty acid synthetase. Arch. Biochem. Biophys. 152:619-630.

de Veth, M. J., J. M. Griinari, A. M. Pfeiffer, and D. E. Bauman. 2004. Effect of CLA on milk fat synthesis in dairy cows: Comparison of inhibition by methyl esters and free fatty acids, and relationships among studies. Lipids 39:365-372.

Glasser, F., M. Doreau, A. Ferlay, and Y. Chilliard. 2007. Technical note: Estimation of milk fatty acid yield from milk fat data. J. Dairy Sci. 90:2302-2304.

Hachey, D. L., M. R. Thomas, E. A. Emken, C. Garza, L. BrownBooth, R. O. Adlof, and P. D. Klein. 1987. Human lactation: Maternal transfer of dietary triglycerides labeled with stable isotopes. J. Lipid Res. 28:1185-1192.
Hara, A., and N. S. Radin. 1978. Lipid extraction of tissues with a low-toxicity solvent. Anal. Biochem. 90:420-426.

Harvatine, K. J., and D. E. Bauman. 2006. SREBP1 and thyroid hormone responsive spot 14 (S14) are involved in the regulation of bovine mammary lipid synthesis during diet-induced milk fat depression and treatment with CLA. J. Nutr. 136:2468-2474.

Harvatine, K. J., Y. R. Boisclair, and D. E. Bauman. 2009. Recent advances in regulation of milk fat synthesis. Animal 3:40-54.

Kang, K., M. Miyazaki, J. M. Ntambi, and M. W. Pariza. 2004. Evidence that the anti-obesity effect of conjugated linoleic acid is independent of effects on stearoyl-CoA desaturase1 expression and enzyme activity. Biochem. Biophys. Res. Commun. 315:532-537.

Kelsey, J. A. B. A. Corl, R. J. Collier, and D. E. Bauman. 2003. The effect of breed, parity, and stage of lactation on conjugated linoleic acid (CLA) in milk fat from dairy cows. J. Dairy Sci. 86:2588-2597.

Kim, C. W., Y. A. Moon, S. W. Park, D. Cheng, H. J. Kwon, and J. D. Horton. 2010. Induced polymerization of mammalian acetyl-CoA carboxylase by MIG12 provides a tertiary level of regulation of fatty acid synthesis. Proc. Natl. Acad. Sci. USA 107:9626-9631.

Loor, J. J., and J. H. Herbein. 2003. Reduced fatty acid synthesis and desaturation due to exogenous trans-10,cis-12-CLA in cows fed oleic or linoleic oil. J. Dairy Sci. 86:1354-1369.

Mackle, T. R., D. A. Dwyer, K. L. Ingvartsen, P. Y. Chouinard, D. A. Ross, and D. E. Bauman. 2000. Evaluation of whole blood and plasma in the interorgan supply of free amino acids for the mammary gland of lactating dairy cows. J. Dairy Sci. 83:1300-1309.

Moore, J. H., and W. W. Christie. 1979. Lipid metabolism in the mammary gland of ruminant animals. Prog. Lipid Res. 17:347-395.

Noble, R. C. 1978. Digestion, absorption and transport of lipids in ruminant animals. Prog. Lipid Res. 17:55-91.

NRC. 2001. Nutritional Requirements of Dairy Cattle. 7th rev. ed. Natl. Acad. Sci., Washington, DC.

Ntambi, J. M. 1999. Regulation of stearoyl-CoA desaturase by polyunsaturated fatty acids and cholesterol. J. Lipid Res. 40:1549-1558.

Oshino, N., and R. Sato. 1972. The dietary control of the microsomal stearyl CoA desaturation enzyme system in rat liver. Arch. Biochem. Biophys. 149:369-377.

Perfield, J. W. II, P. Delmonte, A. L. Lock, M. P. Yurawecz, and D. E. Bauman. 2006. Trans-10, trans-12 conjugated linoleic acid does not affect milk fat yield but reduces $\Delta^{9}$-desaturase index in dairy cows. J. Dairy Sci. 89:2559-2566.

Satter, L. D., and A. N. Bringe. 1969. Effect of abrupt ration changes on milk and blood components. J. Dairy Sci. 52:1776-1780.

Shingfield, K. J., C. K. Reynolds, G. Hervas, J. M. Griinari, A. S. Grandison, and D. E. Beever. 2006. Examination of the persistency of milk fatty acid composition responses to fish oil and sunflower oil in the diet of dairy cows. J. Dairy Sci. 89:714-732.

Spires, H. R., J. H. Clark, R. G. Derrig, and C. L. Davis. 1975. Milk production and nitrogen utilization in response to postruminal infusion of sodium caseinate in lactating cows. J. Nutr. 105:11111121.

Toyama, T., N. Kudo, A. Mitsumoto, Y. Hibino, T. Tsuda, and Y. Kawashima. 2007. Stearoyl-CoA desaturase activity is elevated by the suppression of its degradation by clofibric acid in the liver of rats. J. Pharmacol. Sci. 103:383-390.

Tyburczy, C., A. L. Lock, D. A. Dwyer, F. Destaillats, Z. Mouloungui, L. Candy, and D. E. Bauman. 2008. Uptake and utilization of trans octadecenoic acids in lactating dairy cows. J. Dairy Sci. 91:3850-3861.

Volpe, J. J., and J. C. Marasa. 1975. Regulation of hepatic fatty acid synthetase in the obese-hyperglycemic mutant mouse. Biochim. Biophys. Acta 409:235-248.

Volpe, J. J., and P. R. Vagelos. 1973. Saturated fatty acid biosynthesis and its regulation. Annu. Rev. Biochem. 42:21-60. 